\title{
Relapses in the treatment of genotype 2 viral hepatitis $C$, a cause of concern in the blacks
}

\author{
O. Njoya $\cdot$ L. Ntchama $・$ M. Tagni $\cdot$ I. Dang $\cdot$ M. Kowo
}

Published online: 9 October 2013

(C) Indian Society of Gastroenterology 2013

Sir:

Viral hepatitis C is a worldwide public health problem, as it affects up to $3 \%$ of the general population. It leads to chronic liver diseases namely, cirrhosis and hepatocellular carcinoma. Cameroon is one of the very high-endemic zones with a prevalence of about $13 \%$, where genotype 1,2 , and 4 are predominant [1]. Genotype 2 patients have been so far reported to be the best therapeutic responders [2]. We have noticed, a while ago, that this does not seem to be true.

In Cameroon, we have, so far, fully treated 93 genotype 2 patients, according to international guidelines without any reduction of dose, in the seven treatment centers nationwide. They included 30 women and 63 men aged 37 to 70 years. We have registered 24 failures $(25.8 \%)$. One year after the end of treatment, we have registered 17 relapses $(24.6 \%)$. Ten patients were lost to follow up. This gives an overall failure of at least 41 patients (44\%), 27 men and 14 women, after 1 year.

Therapeutic response of the black population to the treatment of hepatitis $\mathrm{C}$ by pegylated interferon/ribavirin has been reported comparing genotype 2 to genotypes 1 and 4 in a previous study in Cameroon. A response rate of $83.4 \%$ was reported [3]. The current analysis includes the patients of the first study who had been successfully evaluated at the end of

their 6 months of treatment. Even though we are still looking for what could explain this poor response, these observations highlight once more the poor response of the blacks in the treatment of hepatitis $\mathrm{C}$.

There is therefore a need to reconsider the actual guidelines as far as the blacks are concerned, taking into account the fact that most of the patients suffering from hepatitis are found amounted to these populations. This opens the way for more targeted trials.

\section{References}

1. Njouom R, Pasquier C, Ayouba A, et al. High rate of hepatitis C virus infection and predominance of genotype 4 among elderly inhabitants of a remote village of rain forest of south Cameroon. J Med Virol. 2003;71:219-25.

2. Hézode C, Pawlotsky JM, Dhumeaux D. Traitement de l'hépatite chronique C. In: Pawlotsky JM, Dhumeaux D, (eds). Hépatite C. Paris: EDK; 2004. p. 206-25.

3. Njouom R, Sartre MT, Timba I, et al. Efficacy and safety of peg interferon alpha-2a/ribavirin in treatment-naive Cameroonian patients with chronic hepatitis C. J Med Virol. 2008;80:2079-85.
O. Njoya $(\bowtie) \cdot$ L. Ntchama $\cdot$ M. Tagni $\cdot$ I. Dang $\cdot$ M. Kowo

Department Gastroenterology, Réseau Camerounais de Lutte Contre

Hépatite Virales, PO Box 3495, Yaoundé, Cameroon

e-mail: oudou_nj@yahoo.fr 